\title{
Reservasjon og det liberale dilemma
}

\author{
Reservasjonsdebatten illustrerer det liberale dilemma. Samfunnet må verne samvittighetsfriheten og sikre \\ reservasjonsadgang - i motsatt fall svikter det sine liberale grunnverdier.
}

Striden om fastlegers adgang til å reservere seg mot aborthenvisning kan forstås som en konflikt mellom to livssyn, et idealistisk og et pragmatisk. Idealisten - som tilhører et mindretall - bekjenner seg til visse overordnede moralprinsipper som i sin tur er forankret i samvittigheten, og han hevder at disse prinsippene enkelte ganger «lyser over loven». Idealisten vil ofte være kristen eller muslim, men ikke nødvendigvis - han kan også begrunne sitt ståsted sekulært (gjennom for eksempel naturrettstanken, som ligger til grunn for FNs menneskerettighetserklæring). I abortspørsmålet mener idealisten at et foster er et fullverdig menneske, og at en abortkonsultasjon alltid berører to personer - moren og det ufødte barnet.

Pragmatikeren - som tilhører et flertall er skeptisk til overordnede moralprinsipper. Han mener at moral hovedsakelig kommer til uttrykk gjennom samfunnets lover, som i sin tur er formet gjennom rasjonell tenkning og demokratiske prosesser. Helsearbeidere må underordne seg disse lovene, fordi de gjennom en kontrakt forvalter en oppgave på samfunnets vegne. I samfunnslivet er pragmatikeren tilhenger av liberale politiske ideer, som toleranse. Samvittigheten er derimot en privatsak og dessuten en usikker kilde til moralsk innsikt fordi den er koplet til følelseslivet. I abortspørsmålet har et foster ikke samme status som et født menneske, og for pragmatikeren dreier abortkonsultasjonen seg først og fremst om å ivareta den gravide kvinnen.

Ingen passer helt med disse stereotypiene. Men de illustrerer to forskjellige grunnholdninger. Leger med et idealistisk livssyn må ut ifra sine egne forutsetninger - unngå alt som krenker fosterets menneskeverd. En aborthenvisning er en formell del av abortprosessen, og den som underskriver har en annen rolle enn for eksempel drosjesjåføren som bringer kvinnen til sykehuset (1). Kravet fra idealistene om reservasjonsadgang er derfor logisk. Men logikken halter når de samme idealistene går langt i å forsikre at henvisningen vil bli ivaretatt av en kollega (2). Det viktigste for dem - igjen ut fra egne forutsetninger - burde være å motarbeide konsekvensene av henvisningen, altså hindre selve svangerskapsavbruddet. Det idealistiske ståstedet krever noe mer enn passiv reservasjon og timeavtale på nabokontoret. En løsning kan være å forhåndsklarere sitt livssyn og hvilke handlinger man vanskelig kan utføre. Da blir det opp til den abortsøkende selv å velge hvilken fastlege hun vil gå til. Noen gravide kan ønske en konsultasjon som inkluderer etisk meningsutveksling - utfallet kan bli at graviditeten fortsetter
(3). Samtidig ville idealistene, gjennom å være offentlig synlige, bidra til holdningsendring i den retning de selv ønsker.

Leger med et pragmatisk livssyn er gjerne kritiske til sine idealistiske kolleger. Pragmatikeren er for eksempel sterk motstander av å bringe det han mener er private moralstandpunkter inn i legekonsultasjonen. I samme åndedrag advarer han mot å undergrave den samfunnskontrakten som legegjerningen etter hans syn forutsetter. Kritikken virker logisk ut ifra pragmatikerens forutsetninger,

\section{«Når toleransen gjøres absolutt, blir den i praksis intolerant»}

men ved nærmere ettersyn møter også han seg selv i døren. For den tolerante pragmatikeren må - gitt sitt eget grunnsyn - nødvendigvis tolerere kolleger som mener at moralstandpunkter ikke er av privat karakter, men har universell gyldighet. Skal han være tro mot sitt livssyn, må han ha et pragmatisk syn på kolleger som ikke mener at legegjerningen bygger på en samfunnskontrakt, men på profesjonens historiske verdigrunnlag. Og hva gjør pragmatikeren selv dersom staten skulle vedta lover som strider mot grunnleggende liberale ideer, for eksempel et totalforbud mot abort? Reiser han seg i protest? I så fall er han ikke lenger pragmatiker.

Pragmatikerens logikkproblemer er en illustrasjon av det liberale dilemma (4). Når toleransen gjøres absolutt, blir den i praksis intolerant. Reservasjonsdebatten berører derfor en grunnleggende samfunnsutfordring som blir særlig tydelig i en multikulturell virkelighet. Liberale samfunnsteoretikere, som Jürgen Habermas, antyder en vei ut av dette uføret når han oppfordrer til «oversettelse» mellom de ulike livssynene (5). Det liberale samfunn, skriver han, må anerkjenne blant annet samvittighet og religiøse tradisjoner som fullt ut gyldige kilder for moralske oppfatninger. Det er en berikelse, ikke et problem, at enkeltpersoner har andre moralske kilder enn flertallet. En slik ydmyk grunnholdning vil være i det liberale samfunns egen interesse - i motsatt fall utvikles det parallellkulturer med et stort konfliktpotensial.

Dette gir en retning for den politiske håndteringen av reservasjonsspørsmålet. Politikerne har to oppgaver. For det første må de sikre borgerne den rettighet som føl- ger av abortloven, i samsvar med flertallets ønsker. Dette er først og fremst en praktisk utfordring. Om fastlegen skal involveres, er imidlertid ikke gitt. Man kan for eksempel legge opp til at den abortsøkende kontakter en gynekologisk avdeling direkte, på samme måte som en fødende kvinne tar direkte kontakt med fødeavdelingen. For det andre må politikerne sikre likeverdig samfunnsdeltakelse for det idealistiske mindretallet, noe som forutsetter en lovhjemlet reservasjonsadgang. Sagt mer generelt: Politikerne må verne samvittighetsfriheten. Det finnes flere argumenter for dette, blant annet hensynet til idealistene selv (1). Men det viktigste argumentet er samfunnets eget verdigrunnlag. Samvittighetsfrihet sto sentralt da det liberale demokratiet overvant den autoritære statsmakten, slik grunnlovsjubileet minner oss om. Et liberalt samfunn som unnlater å verne samvittighetsfriheten er ikke lenger liberalt, men skyter seg selv i foten.

Europeiske politikere har forstått dette og har gjennom menneskerettslovgivningen etablert et rammeverk som ivaretar begge hensyn (6). Norske politikere ønskes velkommen etter.

\section{Vegard Bruun Wyller}

brwylle@online.no

Vegard Bruun Wyller (f. 1972) er professor ved Universitetet i Oslo, overlege ved Barne- og ungdomsklinikken, Akershus universitetssykehus og medisinsk redaktør i Tidsskriftet. Forfatter har fylt ut ICMJE-skjemaet og oppgir ingen interessekonflikter.

\footnotetext{
Litteratur

1. Clemet C, Magelssen M, Jørgensen HN. Samvittighetsfrihet og legers reservasjonsrett. Civita-notat nr. 17/2012. Oslo: Civita, 2012.

2. Swensen E. Det viktigaste er at fastlegen din kjem til himmelen... Dag og Tid 2.3.2012.

3erg SF. Reservasjonsretten kan være bra for kvinner. Aftenposten 11.10.2013.

4. Skjervheim $\mathrm{H}$. Det liberale dilemma og andre essay. Oslo: Tanum, 1968.

5. Habermas J. Førpolitiske grunnlag for den demokratiske rettsstat? I: Habermas J, Ratzinger J. Sekulariseringens dialektikk. Om fornuft og religion. Oslo: St. Olav forlag, 2008.

6. Helgøy AK. Fastlegers reservasjonsrett ved henvisning til selvbestemt abort. Masteroppgave. Bergen: Det juridiske fakultet, Universitetet i Bergen, ge13.
}

Mottatt 15.2. 2014 og godkjent 17.2. 2014. Redaktør: Erlend Hem.

Publisert først på nett. 